Canadian Journal of Family and Youth, 11(1), 2019, pp. 20-40

ISSN 1718-9748@ University of Alberta

http://ejournals,library,ualberta.ca/index/php/cjfy

\title{
Marital Stress among Working Class Women in Kwara State, Nigeria: Implications for Counselling Practice
}

\author{
Aminat Adeola Odebode
}

\begin{abstract}
This study investigated the sources of marital stress among working class women in Kwara State, Nigeria. The study also examined the influence of age, type of marriage, and length of years in service on the respondents' views. The study employed a descriptive survey method. A total of 422 working class women in Kwara State were selected from a population size of 7,237 through a multi-stage sampling procedure. The participants responded to a researcher-designed questionnaire entitled 'Sources of Marital Stress Questionnaire (SMSQ)'. The validity of the instrument was done by a team of experts (5) from the Department of Counsellor Education, University of Ilorin and the reliability was established using test re-test reliability method, which yielded a correlation coefficient of 0.65 . The data collected were analyzed using both descriptive and inferential statistics at 0.05 level of significance. Results showed that the sources of marital stress of working class women were sexual incompatibility with their spouses, financial constraints, in-laws' interference, and religious differences among others. Results further indicated that there were significant differences in the sources of marital stress among working class women in Kwara State on the bases of age, type of marriage and length of years in marriage. In view of the findings of this study, it was concluded that the sources of marital stress among working class women were numerous. Recommendations were made that counsellors should assist working class women to cope with their sexual incompatibilities with their spouses through appropriate counseling services.
\end{abstract}

Aminat Adeola Odebode, a Lecturer in the Department of Counsellor Education, University of Ilorin, Nigeria obtained her Bachelor of Education (B.Ed.) (2005); Master's degree (M.Ed.) (2010) and Doctor of Philosophy (Ph.D.) (2016) in Educational Guidance and Counselling from the University of Ilorin, Nigeria. Dr. Odebode is a registered teacher with the Teachers' Registration Council of Nigeria (TRCN). She is a member of the Counselling Association of Nigeria and a member of the Association of Professional Counsellors in Nigeria. She is also a Licensed Professional Counsellor of Nigeria (LPCN) and Certified Counsellor of Nigeria (CCN). She is currently an Assistant Post Graduate Seminar Coordinator, Level Adviser and former Departmental Academic Staff Secretary. Her research interests include marital/family life counselling, health counselling, and rehabilitation counselling.

Recent publications:

Oniye, A.O., Odebode, A.A., Adegboyega, L.A. \& Okesina, F.A. (2018). "Marital Breakdown and Socioemotional Development of Adolescents in Ibadan Metropolis, Nigeria". Canadian Journal of Family and Youth, 10(1), 191-204. 
Odebode

Oniye, A.O. Odebode, A.A., Adegboyega, L.A. \& Otaru, B. (2015). "Factors Influencing Pre-marital Sex among Students of Tertiary Institutions in Ilorin, Kwara State, Nigeria: Implications for Counselling." Sokoto International Journal of Counselling Psychology, 3(2), 1-16. http://udusokng.academia.edu/

Odebode, A.A., Adegboyega, L.O. \& Yusuf, T.T. (2015): "Psychosocial Management of Uterine Fibroids among Patients attending University of Ilorin Teaching Hospital". (UITH), Ilorin: Implications for Counselling Practice. The Nigerian Journal of Guidance \& Counselling, 20 (1); 56-67. https://www.ajol.info/index.php/njgc 


\section{Introduction}

Stress is a state of mental or emotional strain resulting from adverse or demanding circumstances. It is a great worry that may be caused by an excessive work demand which could result in burnout. One of the more easily understood concepts of stress is the one which described it as a state of discomfort, tension or emotional pain that arises when an individual is faced with a situation which presents a demand that is necessary for the individual to meet but for which his/her capacities and resources appear inadequate. Stress is common in the day-to-day activities of human beings.

Maisamari (2002) defined stress as an action or situation that places special psychological demands upon a person or anything that can unbalance his/her individual equilibrium. Maisamari further stated that stress can be conceived as a problematic situation for which an individual has no solution at all. This implies that stress arises when ones' coping skills are inadequate for meeting particular problems in life.

The experience of stress can drastically alter a person's behaviour. Sometimes, when stressed, the most noticeable change in behaviour is anger as many people react to the feeling with intermittent rage. Others may react to the feeling with lower resilience, tearfulness, and a tendency to become highly temperamental Odediran (2000) stated that stress can affect all aspects of the sufferer's life, including their emotions, behaviours, thinking ability and physical health. No part of the body is immune. Some may react by engaging in antisocial activities, gambling, heavy smoking and excessive eating or drinking (Health \& Safety Authority, 2015). In extreme cases, other phobic behaviours or compulsions can develop which will need longer term professional intervention to remedy. Irritability as a result of stress can create primary 
Odebode

problems such as the loss of social support. Scientific research has demonstrated that being stressed over a prolonged period of time is associated with medical conditions such as increased blood pressure and cardiovascular problems (Health \& Safety Authority, 2015). It can be concluded that stress could be an adoptive response that threatens any interpersonal relationship including marriage (Omoqui, 2009).

Marriage is a mutual agreement and unique relationship between a man and a woman who are socially, financially, culturally, spiritually and biologically ready to live together as one family to fulfill the roles of husband and wife (Ibrahim, 2005). Marriage also called matrimony or wedlock is a socially or ritually recognized union or legal contract between spouses that establishes rights and obligations between themselves and their children, also their in-laws. Felkins (2005) noted that people marry for a variety of reasons including legal and job-related benefits, to establish a permanent relationship, to get mutual help, to cater for women and children's welfare, or to put their loved ones in bondage because they want to enjoy certain fulfillments in life. Satisfying all these purposes for marriage could bring about stress to the partners, otherwise known as marital stress. A marriage is a titillating relationship but full of different hurdles. Only the understanding and endurance of the partners can sustain the relationship. There are times of joy, excitement and happiness as well as times of confusion, pain and irritation which usually pose stress on the partners. This marital stress is unavoidable because of the couple's disparities in opinions and interests when confronted with different issues in the marriage.

Marital stress can also arise from a number of factors including finances, household responsibilities and unresolved misunderstanding between the couples (Kathy, 2009). One of the largest contributing factors to marital stress is financial 
constraints. When there is insufficient money in the home, the enormous amount of stress that can result can lead to blaming, shaming or arguments that can slowly disrupt the peace in the home. Couples argue over bills, debt, spending and other financial issues. These all increase stress and could result in conflict in the marriage (Omoqui, 2009).

According to Adeniran (2006), marital stress could come from different sources such as living and taking care of a family in the present economic situation and political and social environments, family conflict, education, and the struggle with daily workloads. All can be very stressful and lead to burn out. As a result of an overload of responsibility, couples may be found yelling at each other over minor incidents such as cooking food late. Similarly, the interference of in-laws, siblings, children, stepchildren, friends and neighbours can all create stress within marriage. Pete (2007) stated that if one is surrounded by friends and family, chances are that, it may lead to stress. Pete stressed that poisonous or possessive friends, controlling family members and even "noisy neighbours" can create tension and discord within a relationship. They could also cause stress with their judgments, opinion and advice.

Sex is a source of stress for couple. When there is lack of, or inadequate sexual satisfaction in marriage, there might be disagreement and resentment between the couple because sex is a primary factor for marital fulfillment and a potential source of marital stress among couples. In the view of Oniye (2016), sex makes marriage colourful; it is the most powerful marital "glue" a couple could have. Leman (2005) added that a sexually fulfilled man will normally be a better father and better employer while a sexually fulfilled woman will have less stress and more joy in her life. By 
Odebode

implication, this signifies that an unsatisfactory sex life could lead to conflict and crisis. According to Pete (2007), too much, not enough, or not the right kind of sex in a marital relationship is one of the biggest and more common reasons for marriage difficulties. Pete (2007) explained further that unmet sexual expectation is a significant reason for arguments, hard feelings and divorce among married people or couples.

The work-family conflict is another trend in the sources of marital stress, most especially for teachers. Family and work life is mutually dependent and interconnected with each other as one area of life is affected by experience in other areas (Anderson, 2002). A study by Stonge (2002), involving 1,306 respondents revealed that employees who feel that the demands of their professional life conflict with those of their family life are less satisfied with life in general, as well as with their family life.

Teachers in primary schools who carry dual responsibilities within the school and teach all subjects and at the same time, perform the class teacher's role. But in secondary system, they use subject teachers to teach individual subjects; lecturers in higher institutions use a lecturing method for their students. Pupils in primary school are still in their formative years, and teachers will have to spend more time teaching, monitoring, cautioning and directing them. Whereas, in secondary school, students are adolescents and more mature, just as it is the case of students in higher institutions. In addition, teaching is particularly very difficult in public schools because of a lack of facilities and motivations. These put together could lead to marital stress.

It has been observed that the teaching occupation is a very stressful field and has the tendency of interfering with marital issues thereby creating stress. The assumption of the researcher is that number of children, type of marriage, age and length 
of years in service could affect the sources of stress in the home and the consequent adjustment strategies employed. It is on this premise that this study investigated the sources of marital stress and adjustment strategies of working class women in Kwara State, Nigeria.

\section{Research Questions}

In relation to the statement of the problem, the following research question was raised and answered in this study:

1. What are the sources of marital stress among working class women in Kwara State?

\section{Research Hypotheses}

The following research hypotheses were formulated and tested in this study:

1. There is no significant difference in the sources of marital stress of female working class women on the basis of age.

2. There is no significant difference in the sources of marital stress of working class women on the basis of type of marriage.

3. There is no significant difference in the sources of marital stress of working class women on the basis of length of years in service.

\section{Research Design}

The researcher employed a descriptive survey research method to investigate the sources of marital stress. The population of the present study comprised working class women in Kwara State (female teachers working in private and public primary 
Odebode

schools); estimated to be 14,207 in number (Kwara State Teachers' Census Report, 2015/2016). The target population was therefore female teachers in selected public primary schools in Kwara State.

Based on the population of working class women from the sixteen Local Government Areas, the sample for this study was 384 (Research Advisor, 2006) at 95\% confidence level, under $10 \%$ margin of error and against a population size of 14,207. However, $10 \%$ of 384 were added to cater for attrition rate and to cover a wider sample. This made 422 respondents selected for the study. There are three senatorial districts in Kwara State; Kwara Central, Kwara North and Kwara South out of which there are 16 Local Government Areas. Therefore, at stage 1, a proportional sampling technique was used in the ratio 3:2:2 to choose 7 Local Government Areas from Kwara South, North and central respectively. At stage 2, purposive sampling technique was employed to select three primary schools which have densely populated female primary school teachers from each of the seven selected Local Government Areas in the three senatorial districts. This made a total of 21 primary schools that were selected for the study. At stage 3, a simple random sampling technique was used to select 21 female teachers in each of the primary schools. The dip hat method was adopted to give all the female teachers a fair chance of participating in the study. This made a total of 422 respondents that were selected to cover losses that may arise after the administration of the questionnaire in the study.

The instrument used for data collection from the respondents was a researcher designed from a literature view questionnaire entitled "Sources of Marital Stress Questionnaire (SMSQ). The instrument was a structural questionnaire consisting of three main sections. Section 'A' dealt with demographic data of the respondents such 
as, age, type of marriage and number of children. Section 'B' contained 15 items which sought to elicit information on sources of marital stress. The questionnaire which was patterned on the four-point Likert type rating scale format reflected different levels of respondents responses as $\mathrm{SA}=\mathrm{Strongly}, \mathrm{A}=$ Agree, $\mathrm{D}=$ Disagree, and $\mathrm{SD}=$ Strongly Disagree. The instrument was validated by five experts in the Department of Counsellor Education, University of Ilorin, Nigeria. The test re-test method of ascertaining reliability was employed in this study. The instrument was administered twice within an interval of four weeks to the same group of respondents. The two sets of score obtained were correlated using Pearson's Product Moment Correlation analysis. A Coefficient of 0.65 was obtained; this implies that the instrument was reliable for the study. In order to answer the research questions for the study, the assigned four-point LikertType scoring was modelled on average mean scores. This follows that mean scores from 2.5 and above indicated the source(s) of marital stress among female teachers while mean scores below 2.5 were not regarded as the sources of stress and adjustment strategies of female teachers. The data were analysed using t-test and Analysis of Variance (ANOVA) statistical procedures to compare the mean scores of variables. Percentages was used to analyse demographic data. Mean and rank order were used to analyse the main research question.

\section{Demographic Data}

The demographic data were analyzed using descriptive statistics of percentage. This is presented as follows. A total of 422 respondents participated in the study; out of which $25(5.9 \%)$ were below 18 years, 68(16.1\%) of the respondents were between 
Odebode

19-27 years, 107(25.4\%) were between 28-37 years, 154(36.5\%) were between 38-47 years while $68(16.1 \%)$ of the respondents were between 48 years and above. This implied that respondents who are between the ages of 38-47 years participated most in the study than other age groups. Based on marital status, $345(81.8 \%)$ of the respondents are from monogamous families while $77(18.2 \%)$ of the respondents are from polygamous families. This implied that respondents who are from monogamous families participated more in the study. On length of years in service, $21(5.0 \%)$ of the respondents have spent less than 1 year in service, 127(30.1\%) respondents have spent between 2-5 years in service, 135(32.9\%) of the respondents have spent 6-10 years in service, while, $139(32.0 \%)$ of the respondents have spent 11 years and above in service. This implied that respondents who have spent between 6-10 years in service participated most in the study.

\section{Research Question 1: What are the sources of marital stress of working class women in Kwara State?}

Table 1: Mean and Rank Order of Sources of Marital Stress of Working Class Women in Kwara State

\begin{tabular}{llll}
\hline Item & I experience stress in my marriage as a result of: & Mean & Rank \\
No. & & & \\
\hline 2. & Sexual incompatibility with my spouse & 3.73 & $1^{\text {st }}$ \\
1. & Financial constraints & 3.61 & $2^{\text {nd }}$ \\
8. & In-laws' interference & 3.60 & $3^{\text {rd }}$ \\
4. & Religious differences between myself and my spouse & 3.43 & $4^{\text {th }}$ \\
9. & My spouse not respecting my opinion & 3.38 & $5^{\text {th }}$ \\
15. & My busy work schedule e.g. having to write lesson notes daily. & 3.32 & $6^{\text {th }}$ \\
6. & Ineffective communication between myself and my spouse & 3.30 & $7^{\text {th }}$ \\
5. & Emotional distance between me and my spouse & 3.22 & $8^{\text {th }}$ \\
10. & Childlessness & 3.14 & $9^{\text {th }}$ \\
14. & My children being of same sex i.e. male or female & 3.10 & $10^{\text {th }}$ \\
13. & My spouse not having time schedule & 2.99 & $11^{\text {th }}$ \\
7. & Child rearing difficulties & 2.96 & $12^{\text {th }}$ \\
12. & Irreconcilable differences with my spouse & 2.95 & $13^{\text {th }}$ \\
3. & Overwhelming household responsibilities & 2.90 & $14^{\text {th }}$ \\
11. & Maltreatment by my spouse & 1.85 & $15^{\text {th }}$
\end{tabular}


Table 1 shows the mean and rank of sources of marital stress of working class women in Kwara State. Item 2 which stated, 'sexual incompatibility with my spouse' with mean score 3.73 ranked 1st. Item 1 which stated, 'financial constraints' with mean score 3.61, ranked $2^{\text {nd }}$. Item 8 which stated 'in-laws' interference' ranked $3^{\text {rd }}$ with mean score 3.60. Item 11 which stated, 'maltreatment by my spouse' ranked $15^{\text {th }}$ with mean score 1.80 .

Since the cut-off point for taking decision on the sources of marital stress of working class women in Kwara State is 2.5 and 14 out of the 15 items have mean scores above the cut-off, it can then be concluded that the sources of marital stress of working class women in Kwara State are numerous. The most significant are: sexual incompatibility with their spouse, financial constraints, in-laws' interference, religious differences between them and their spouse, their spouse not respecting their opinion, their busy work schedule e.g. having to write lesson notes daily among other sources.

\section{Hypotheses Testing}

Three null hypotheses were formulated and tested for this study. The hypotheses were tested using t-test and ANOVA statistical methods at 0.05 level of significance. The results are presented as follows:

\section{Hypothesis One: There is no significant difference in the sources of marital stress of working class women in Kwara State based on age.}


Odebode

Table 2: $\quad$ Analysis of Variance (ANOVA) on Sources of Marital Stress of Working class women in Kwara State Based on Age

\begin{tabular}{llrrrrrr}
\hline Age & SS & df & MS & $\begin{array}{l}\text { Cal. } \\
\text { F-ratio }\end{array}$ & $\begin{array}{l}\text { Crit. } \\
\text { F-ratio }\end{array}$ & p-value & Decision \\
\hline Between group & 6719.316 & 4 & 1679.829 & $46.75^{*}$ & 2.37 & 0.00 & Significant \\
Within group & 14982.798 & 417 & 35.930 & & & & \\
Total & 21702.114 & 421 & & & & & \\
& & & & & & & \\
\hline
\end{tabular}

*Significant, $\mathrm{p}<0.05$

Table 2 indicates that the calculated F-ratio is 46.75 while critical F-ratio is 2.37. Since the calculated F-ratio is greater than the critical F-ratio at 0.05 alpha level, the hypothesis is rejected. This means that there is a significant difference in the sources of marital stress of working class women in Kwara State on the bases of age. However, a post-hoc analysis Duncan Multiple Range Test (DMRT) was further conducted to identify where the difference lies amongst the variables.

Table 3: Duncan Multiple Range Test (DMRT) Output for Differences in the Sources of Marital Stress of Working Class Women in Kwara State based on Age

\begin{tabular}{lcccc}
\hline Age & Group & N & Mean & Duncan Groupings \\
\hline Below 18years & 1 & 25 & 40.21 & A* \\
19-27years & 2 & 68 & 28.00 & B \\
28-37years & 3 & 68 & 32.94 & C \\
38yrs-47years & 4 & 154 & 29.90 & D \\
48years \& above & 5 & 107 & 31.04 & E \\
\hline
\end{tabular}

Table 3 shows the Duncan Multiple Range Test (DMRT) output for significant difference. The findings show that respondents below 18 years have a mean score of 40.21, respondents between 28-37 years have a mean score of 32.94, respondents 
between 38-47 have a mean score of 29.90 while respondents between 48 years and above have a mean score of 31.04. Thus, respondents below 19 years, experience more sources of marital stress when compared to those of other age groups.

Hypothesis Two: There is no significant difference in the sources of marital stress of working class women in Kwara State based on marriage type.

Table 4: Mean, Standard Deviation and t-value on Sources of Marital Stress of Working Class Women in Kwara State based on Marriage Type

\begin{tabular}{lccccccc}
\hline $\begin{array}{l}\text { Marriage } \\
\text { Type }\end{array}$ & N & Mean & SD & Df & Cal. val. & Crit. val. & Decision \\
\hline Monogamy & 345 & 33.23 & 7.60 & & & & \\
& & & & 420 & $2.19^{*}$ & 1.96 & Significant \\
Polygamy & 77 & 35.92 & 4.22 & & & & \\
\hline
\end{tabular}

*Significant, $\mathrm{p}<0.05$

Table 4 indicates that the calculated t-value is 2.19 while, the critical t-value is 1.96. Since the calculated t-value of 2.19 is greater than the critical t-value of 1.96 at 0.05 level of significance, the hypothesis is rejected. This means that there is a significant difference in the sources of marital stress of working class women in Kwara State based on marriage type.

Hypothesis Three: There is no significant difference in the sources of marital stress of working class women in Kwara State based on length of years in service. 
Odebode

Table 5: Analysis of Variance (ANOVA) on Sources of Marital Stress of Working Class Women in Kwara State based on Length of Years

\begin{tabular}{llllllll}
\hline $\begin{array}{l}\text { Length of Years } \\
\text { In Service }\end{array}$ & SS & Df & MS & $\begin{array}{l}\text { Cal. } \\
\text { F-ratio }\end{array}$ & $\begin{array}{l}\text { Crit. } \\
\text { F-ratio }\end{array}$ & p-value & Decision \\
\hline Between group & 5912.289 & 3 & 1970.763 & $52.17 *$ & 2.60 & 0.00 & Significant \\
Within group & 15789.825 & 418 & 37.775 & & & & \\
Total & 21702.114 & 421 & & & & & \\
& & & & & & & \\
\end{tabular}

*Significant, $\mathrm{p}<0.05$

Table 5 indicates that the calculated F-ratio is 63.58 while critical F-ratio is 2.60 .

Since the calculated F-ratio is greater than the critical F-ratio at 0.05 alpha level, the hypothesis is rejected. This means that there is a significant difference in the sources of marital stress of working class women in Kwara State based on length of years in service. However, a post-hoc analysis Duncan Multiple Range Test (DMRT) was further conducted to identify where the difference lies amongst the variables.

Table 6: Duncan Multiple Range Test (DMRT) Output for Differences in the Sources of Marital Stress of Working Class Women in Kwara State based on Length of Years in Service

\begin{tabular}{lllll}
\hline $\begin{array}{l}\text { Length of Years } \\
\text { Service }\end{array}$ & Group & $\mathrm{N}$ & Mean & Duncan's Grouping \\
\hline Less than 1year & 1 & 21 & 38.13 & $\mathrm{~A}^{*}$ \\
2-5years & 2 & 135 & 36.43 & $\mathrm{~B}$ \\
6-10 years & 3 & 127 & 34.15 & $\mathrm{C}$ \\
11yrs \& Above & 4 & 139 & 28.88 & D \\
\hline
\end{tabular}

Table 6 shows the Duncan Multiple Range Test (DMRT) output for significant difference. The finding shows that respondents who have spent 11 years and above in service have a mean score of 28.88 which is slightly different from the mean score of 
those who have spent between 1-5- years and 6-10 years in service with mean scores of 34.15 and 36.43. However, these means are significantly different from a mean score of 38.13. Thus, respondents who have spent below 1 year in service experience more sources of marital stress when compared to other groups.

\section{Discussion}

The findings of this study revealed that the sources of marital stress of working class women in Kwara State were numerous and the most significant were sexual incompatibility with their spouse, financial constraints, in-laws' interference, religious differences between them and their spouse, their spouse not respecting their opinion, and their busy work schedule (e.g. having to write lesson notes daily among other sources.) This finding tallied with the findings of Kathy (2009) which showed that marital stress can arise from many factors such as a sexual factor, finances, household responsibilities, and unresolved misunderstandings between couples. This finding also agrees with that of Pete (2007) which concluded that unmet sexual expectations among couples is a significant source of marital stress. Similarly, the findings of this study corresponds with the findings of Felkins (2005) which revealed that in-laws' interference could be a source of marital stress. The finding of this study is also in agreement with the findings of Adeniran (2006) which concluded that marital stress could manifest in numerous ways such as living and taking care of a family in the present economic situation. The reason for this finding could be that marriage which is the union between two consenting individuals establishes rights and obligations on the couples. Obligations such as providing for the family, taking care of the husband, being 
Odebode

emotionally present for the family members, and combining work and family. Satisfying these obligations could culminate into marital stress. Women who are the respondents of this study could be at the receiving end of marital stress therefore they responded the way they did in the study.

Findings also revealed that there was a significant difference in the sources of marital stress of working class women in Kwara State based on age. This implies that the age of female married teachers has considerable influence on their sources of marital stress. It also meant that as there are respondents of different age groups, so there are differences in their sources of marital stress. This finding concurred with that of Miller and Daniel who also found a significant difference based on age. This finding also corroborated that of Abdul-Qyyum and Chaudhry (2012) who found a significant difference based on age as regards stress among teachers. Similarly, the finding is in consonance with that of Kyriacou (2001) which revealed that age significantly influenced the sources of marital stress. However, further analysis revealed that respondents below 18 years experienced more sources of marital stress when compared to those of other age groups. This finding could be that respondents below 18 years are still young compared to respondents of other age groups and are just adjusting to new work life and marital life situations. They are in the process of settling down and therefore, are bound to experience many sources of marital stress.

Another finding revealed that there was a significant difference in the sources of marital stress of working class women in Kwara State based on the type on marriage. This implied that marriage that has a significant influence on the sources of marital stress of working class women in Kwara State. This also means that marriage type influences the expression of working class women on the sources of marital stress. This 
finding is in agreement with that of Akinade (2007) and Klotzle (2009) who revealed that the type of marriage could induce a considerable influence on marital stress. The findings of this study further revealed that working class women who are from polygamous marriages experienced more sources of stress. This finding could be that not many females would be happy sharing their husband with another woman. Being in a polygamous family is enough to bring about marital stress. Therefore, the turnout of this finding is not surprising.

Findings showed that there was a significant difference in the sources of marital stress of working class women in Kwara State based on length of years in service.This implied that length of years in service has a noteworthy influence on the sources of stress of working class women in Kwara State. This also means that length of years in service influenced the expression of working class women on their sources of marital stress. This finding agreed with that of Ofoegbu (2006) who found in a study that length of years has a significant influence in the source of marital stress. Conversely, the finding is in nonconformity with that of David (2006) which revealed that length of years in service does not influence the sources of marital stress. However, further analysis showed that respondents who have spent less than 1 year in service experienced more sources of marital stress when compared to other groups. The finding of this study could be that respondents who have spent less than 1 year in service have an inability to be settled in their jobs which could also create more stress in their homes.

\section{Conclusion}

The sources of marital stress of working class women in Kwara State are numerous 
Odebode

among which are sexual incompatibility with their spouse, financial constraints, and inlaws' interference. Age, type of marriage and length of years in service in marriage have no significant difference in the sources of marital stress of working class women in Kwara State.

\section{Implications of the Findings for Counselling Practices}

The sources of marital stress of working class women in Kwara State are numerous and the most significant are sexual incompatibility with their spouse, financial constraints, in-laws' interference, religious differences between them and their spouse, their spouse not respecting their opinion, and their busy work schedule (e.g. having to write lesson notes daily among other requirements). Therefore, counsellors should organize couple-based workshops, town halls, meetings at PTA and seminars in communities to discuss the sources of marital stress and how to overcome or reduce marital stress. Counsellors should enlighten couples through marital counselling, the importance of sex in marriage and how couples can talk over their incompatibility. Working class women should be taught how to manage household and work responsibilities. Counsellors should also make counselling services available for working class women to reduce the sources of marital stress. The finding of this study also showed that there were significant differences in the sources of marital stress of working class women in Kwara State based on age, number of children, type of marriage and length of years in marriage. This implied that counsellors should be ready to assist female teachers manage their sources of marital stress irrespective of age, 
Marital Stress Among Working Class Women in Kwara State, Nigeria

number of children, type of marriage and length of years in service and come up with strategies that addresses their differences. 
Odebode

\section{References}

Abdul-Qayyum C. (2012). Relationship between occupational stress and job satisfaction: The case of Pakistani Universities. International Education Studies, 5(3), 39-43.

Akinade, E.A. (2007). Stress: Understanding and managing it. Lagos: Pumark Publishers.

Anderson, E.S. (2002). Formal organizational initiatives and informal workplace practices: Links to work-family conflict and job-related outcomes. Journal of Management, 28-787.

David, G.F. (2006). Sources of marital stress and adjustment strategies as reported by married literate persons in Ilorin Metropolis. Unpublished (M.Ed Thesis). University of Ilorin, Nigeria.

Felkins, L. (2005). The memes of love, sex and marriage. Retrieved September 10, 2009, from http://leon@perspecuith.net.

Health and Safety Authority (2015). Work-related stress: A guide for employers. Republic of Ireland: Health and Safety Authority.

Ibrahim M.B. (2005). A framework for studying personality in the stress process. Journal of Personality and Social Psychology, 69, 890-902.

Kathy, N. (2009). Keeping stress in a marriage from causing problems. Retrieved September 9, 2009, from http:// eziearticle.coml?/expert.html

Klotzle, J. (2009).God in our stress: The christianguide to stress management. Retrieved October 10, 2013 from http://www.christian-life-coachingorglindex.html.

Kyriacou, C. (2001). Teacher stress: Directions for future research. Educational Review, 53(1), 27-35.

Leman, K. (2005). How important in sex in marriage. Electronic Journal of Sexuality. Retrieved on May 21, 2009, from www.ehqs.orq.

Maisamari, J. Y. (2002) Stress and stress management strategies. Kaduna, Joyce Printers and Publishers Co.

Odediran, N.O. (2000). Counselling for effective educational process in Nigeria: Problems and 'prospects. The Counsellor, 18(1), 84-90.

Ofoegbu, F.N. (2006). Level of perceived stress among teacher's in Nigeria universities. Educational psychology and mental health. Journal of Instructional Psychology, 2(12), 20-31. 
Marital Stress Among Working Class Women in Kwara State, Nigeria

Oniye, A.O. (2016). Concept and types of marriage. In L.A. Yahaya, M.O. Esere, J.A. Ogunsanmi\& A.O. Oniye. (Eds) Marriage, sex and family counselling. (pp. 127.). Ilorin: Unilorin Press Ltd.

Pete, R.E. (2007). Does friendship matter? An examination of social physique anxiety in adolescence.Journal of Applied Social Psychology, 37,1248-1268.

Stonge, D.B. (2002). Occupational stress in head teachers: A national UK study. British Journal of Educational Psychology, 63, 130-143 